\title{
Studies on the Hall-Heroult Aluminum Electrowinning Process
}

\author{
Shiva Prasad \\ Departamento de Engenharia Química, CCT, Universidade Federal da Paraíba, \\ CP 10108, 58109-970, Campina Grande - PB, Brazil
}

\begin{abstract}
Estudos da eletrólise da criolita-alumina fundida mostraram que nas melhores condições de operação, a $960{ }^{\circ} \mathrm{C}$, a eficiência energética é de apenas 33\%. Encontrou-se que para o funcionamento estável da célula a $3 \%$ de alumina a relação $\mathrm{NaF} / \mathrm{AlF}_{3}$, em peso-percentual, deve ser no mínimo 1,11. Encontrou-se ainda que a fileira de ânodos posicionada junto a "down-stream" está sujeita a uma turbulência mais intensa, de modo que elevando-se o nível desta fileira em $4 \mathrm{~cm}$, resulta em uma diminuição no número de "burnoffs". A seleção cuidadosa do material de revestimento da célula aumentou sua vida útil. A estabilidade da interface alumínio-banho é um dos principais fatores que afetam a eficiência de corrente. Uma modificação na célula foi proposta para se ter uma melhor estabilidade na interface alumínio-banho. $\mathrm{O}$ novo desenho proposto para a célula permite uma redução da distância cátodo-ânodo, diminuindo a voltagem e consequentemente, melhorando a eficiência anódica.
\end{abstract}

Studies on the electrolysis of cryolite-alumina melt showed that even the best equipped smelter, functioning at $960{ }^{\circ} \mathrm{C}$, has only 33\% energy efficiency. For stable functioning of the smelter at $3 \%$ alumina the minimum $\mathrm{wt} \%$ ratio $\mathrm{NaF} / \mathrm{AlF}_{3}$ was found to be 1.11 . The anodes located on down-stream row were found to face more turbulence; raising their level by $4 \mathrm{~cm}$ resulted in decreasing the number of burnoffs. A careful selection of potlining material improved the pot life. The stability of the aluminum-bath interface is one of the major factors affecting the current efficiency. An improved cell design has been proposed to achieve the ultimate aluminum-bath interface stability. The proposed cell design should allow a reduction of the cathode-to-anode distance producing a lower voltage and improving the power efficiency.

Keywords: aluminum electrowinning, Hall-Heroult process, electroreduction

\section{Introduction}

The commercial production of metallic aluminum started in 1889 with electrolysis of cryolite-alumina melt by the Hall-Heroult process. Apart from the technological refinements made since, the electrolytic aluminum process remains basically the same, as it was 110 years ago ${ }^{1}$. Numerous alternatives to the $\mathrm{H}-\mathrm{H}$ process have been considered over the years, attempting to reduce the cost of the metal, but no one could replace it due to technical problems ${ }^{2}$. The changing economic conditions make the development of low-cost cells vital for the industry. Potential improvements to the process that have received considerable attention in recent years are: increase in current efficiency, development of nonconsumable anodes and more resistant potlining, reduction in energy losses, and optimization of the bath composition. Results of a modest attempt by the author in some of these areas are given in this paper. A long involvement of the author in the areas such as electrodeposition of alloys ${ }^{3}$, electroreduction of aluminum 4 and chemistry of bauxite5; and a recent integration program with Alumar (UFPB-PRODENGE/ ALUMAR) has helped to conclude this work. The work was realized by the author in the premises of Alumar.

\section{Basics and bath chemistry of the Hall-Heroult process}

The electrolysis is performed in a pot (cell) of steel box lined with a refractory, thermal insulator and carbon. In fact, the base of the pot is lined with prebaked carbon blocks and the sides with partially graphitized anthracite in coaltar pitch. Carbon anodes are manufactured from a carbon source such as coke and a pitch binder. Two types of anodes are in use: pre-baked carbon blocks and self-baking (known as Soderberg type). The latter type anodes were common in 1940s and 1950s, and are now being replaced by more efficient pre-bake anodes. Figure 1 shows a cross sectional schematic of an industrial Hall-Heroult cell with pre-baked anodes. While the electrolyte is essentially molten cryolite, 
certain additions are made and a typical electrolysis medium also contains excess $\mathrm{AlF}_{3}(10-12 \%)$ and $\mathrm{CaF}_{2}$ (4-6\%) along with a regular feeding of alumina. The additives increase the conductivity of the medium and lower the melting point of the cryolite from 1011 to $920-970{ }^{\circ} \mathrm{C}$ resulting in decrease in energy consumption. But the additives cause a decrease in the solubility of alumina (from 15 -wt $\%$ to about 6-wt $\%$ ) and this limits the total concentration. Alumina is added to the cell periodically because during the electrolysis its concentration drops, and if it is allowed to fall below about $2 \%$, the electrolysis cell undergoes a sudden and major operational failure known as an 'anode effect'. The cell voltage increases rapidly from $4.5 \mathrm{~V}$ to a value in the range of -40 to $-60 \mathrm{~V}$. Overfeeding of the cell with alumina causes formation of a sludge under the molten aluminum pad decreasing the electrical conductivity and resulting in a 'sick pot'. The optimum current density is around $1 \mathrm{~A} \mathrm{~cm}^{-2}$ with a total cell current of $150-300 \mathrm{kA}$ and a cell voltage -4.0 to $-4.5 \mathrm{~V}$. A typical cell house will contain about 200 cells arranged in series on two lines. All cell houses have a strong magnetic field due to the large currents used. The field can produce turbulence at the aluminum/electrolyte interface if the bus bars are not arranged in a compensating manner. Aluminum is probably present as a mixture of several oxy-fluoride species in the electrolyte. Therefore the exact chemistry of the system is not known. However, the cathode reaction is reduction of $\mathrm{Al}(\mathrm{III})$ species to the metal forming a pool of liquid aluminum at the bottom of the pot and acting as cathode. The anode reaction should be the oxidation of oxide ion to oxygen, but it is difficult to find an anode material which is inert under the aggressive conditions of electrolysis. Hence the electrolysis has always been run with consumable carbon anodes so that the overall cell reaction is:

$2 \mathrm{Al}_{2} \mathrm{O}_{3}+3 \mathrm{C}=4 \mathrm{Al}+3 \mathrm{CO}_{2}$

Some undesired reactions also take place in the pot, which are mainly responsible for the loss of current efficiency. The aluminum metal may react with components of the bath to produce dissolved metal in the bath. The main reactions forming the dissolved metal are:

$3 \mathrm{NaF}($ bath $)+\mathrm{Al}(\mathrm{Al}$ pad $) \rightleftharpoons 3 \mathrm{Na}($ bath and $\mathrm{Al}$ pad $)+$ $+\mathrm{AlF}_{3}$ (bath)

$\mathrm{AlF}_{3}$ (bath) $+2 \mathrm{Al}(\mathrm{Al}$ pad $) \longrightarrow 3 \mathrm{AlF}$ (bath)

The equilibrium (2) produces a concentration of sodium dissolved in both the aluminum and the bath. This concentration increases as the $\mathrm{NaF}: \mathrm{AlF}_{3}$ ratio at the aluminum-bath interface increases. At the same time equilibrium (3) produces an interfacial concentration of monovalent aluminum species in the bath. This concentration increases as the $\mathrm{NaF}: \mathrm{AlF}_{3}$ ratio at the interface decreases. Equilibria (2) and (3) shift to the right with increasing temperatures producing higher interfacial concentrations of reduced species leading to lower current efficiency 6 . Since sodium is the predominant dissolved metal a low $\mathrm{NaF}: \mathrm{AlF}_{3}$ ratio promotes higher current efficiencies 6 .

The reactions oxidizing the dissolved metals $(\mathrm{Na} \& \mathrm{AlF})$ are:

$$
\begin{aligned}
& 6 \mathrm{Na}(\text { bath })+ 3 \mathrm{CO}_{2}(\mathrm{~g})+2 \mathrm{AlF}_{3}(\text { bath }) \rightarrow \\
& \mathrm{Al}_{2} \mathrm{O}_{3}(\text { bath })+6 \mathrm{NaF}(\text { bath })+3 \mathrm{CO}(\mathrm{g}) \\
& 3 \mathrm{AlF}(\text { bath })+ 3 \mathrm{CO}_{2}(\mathrm{~g}) \rightarrow \mathrm{AlF}_{3}(\text { bath })+ \\
& \mathrm{Al}_{2} \mathrm{O}_{3}(\text { bath })+3 \mathrm{CO}(\mathrm{g})
\end{aligned}
$$

For reactions (2) through (5) to take place, $\mathrm{AlF}_{3}$ must

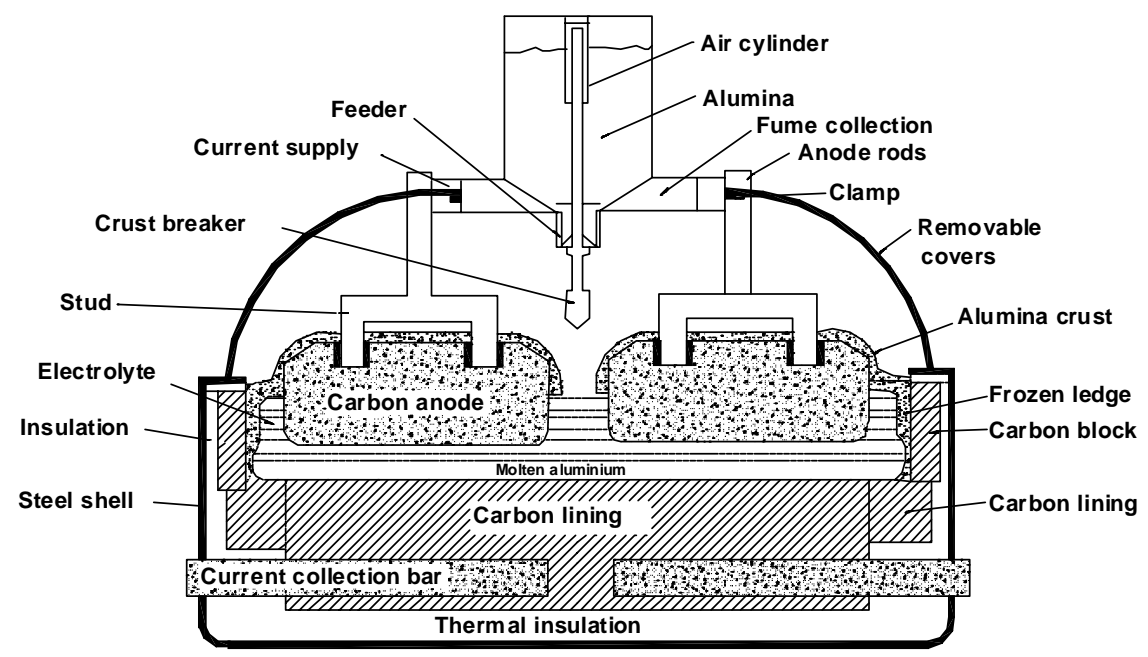

Figure 1. Cross sectional scheme of an industrial Hall-Heroult cell with prebaked anodes. 
diffuse in through the cathode boundary layer. $\mathrm{NaF}$ and dissolved metal must diffuse out. $\mathrm{Na}^{+}$is transported in by the current but does not discharge because aluminum from $\mathrm{AlF}_{3}$ discharges at a lower potential than sodium. The result is a higher $\mathrm{NaF}: \mathrm{AlF}_{3}$ ratio at the interface than in the bulk $^{7}$. Thicker boundary layers decrease mass transport raising both $\mathrm{NaF}$ and $\mathrm{Na}$ concentrations at the interface, but the thicker boundary layer lets less dissolved metal to diffuse out. Measurements have shown that convective transport of dissolved metal through the bath and its reaction with $\mathrm{CO}_{2}$ are fast. Diffusion of dissolved metal through the boundary layer at the cathode is the slow or rate limiting step. For a given boundary layer thickness, the total amount of dissolved metal diffusing out is proportional to the cathode area. Hence a high cathode current density improves the current efficiency because more aluminum is made compared with the dissolved metal entering the bath to be reoxidized6.

Impurities may also enter the bath, mainly with alumina and carbon anodes, participating in reactions and decreasing the current efficiency. Multivalent impurities, in the form of anionic complexes, of $\mathrm{Fe}^{3+}, \mathrm{Ga}^{3+}, \mathrm{Ni}^{3+}, \mathrm{V}^{5+}$ and $\mathrm{Cr}^{6+}$ diffuse into the boundary layer and are reduced to a lower valence state as they meet dissolved metal diffusing out $^{8}$. A fraction of each impurity continues on to be fully reduced and alloy with the aluminum. The rest diffuses out at the boundary layer and is transported by convection to the vicinity of the anode where each is reoxidized by $\mathrm{CO}_{2}$ forming $\mathrm{CO}$ and oxidized impurity. Convection takes these reoxidized impurities back to the cathode to repeat the cycle. Transport through the cathode boundary layer remains the rate controlling step, but the impurities diffusing into the boundary layer reduce the distance through which the dissolved metal must diffuse. The lowering of current efficiency by impurities in the bath has been confirmed experimently 6 .

\section{Experimental}

The work was carried out on electrolysis pots made of steel box (9.96 m length, $3.97 \mathrm{~m}$ breadth, $1.175 \mathrm{~m}$ height) lined with a refractory, thermal insulator (Figure 1). The base of the pot was lined with prebaked carbon blocks and the sides with partially graphitized anthracite in coal-tar pitch. Two rows of 12 anodes, each of prebaked carbon blocks manufactured from coke and a pitch binder, were used in each pot. Each anode was of $154.94 \mathrm{~cm}$ length, $72.07 \mathrm{~cm}$ width and $61.91 \mathrm{~cm}$ height. The gap between two anodes was $3.78 \mathrm{~cm}$ and the aisle width: end $33.97 \mathrm{~cm}$, side 21.91 $\mathrm{cm}$, and center $16.51 \mathrm{~cm}$. The cell functioned at about 4.45 $\mathrm{V}, 216 \mathrm{kA}$ and $960^{\circ} \mathrm{C}$ with a metal level of $10 \mathrm{~cm}$ and a bath level of $19 \mathrm{~cm}$. The bath composition was $11.8 \mathrm{wt} \%$ excess
$\mathrm{AlF}_{3}, 5.5 \mathrm{wt} \% \mathrm{CaF}_{2}, 3 \% \mathrm{Al}_{2} \mathrm{O}_{3}$ and the rest of cryolite. Three point feeders in each pot allowed alumina feeding.

The process was controlled by a computer system using sophisticated software. The control and decision making was based on voltage comparison. The overall control strategy included the control of the variables that change in the short-term (alumina concentration, cell voltage, inter-electrode separation), making allowance for slowly changing variables but having an overriding system for the abnormalities (sludging, anode effects, shortcircuited anodes, accumulation of carbon dust in the bath). The control system also provided printed as well as spoken (speechmaker) messages.

The control problem in the cells is very complex. The cell variables are inter-related in such a complex way that decision-making is a difficult task. For example, the change in cell temperature can be attributed to any of the following parameters: cell voltage, cell current, feed cycle, alumina concentration, depth of metal pad, ledge formation, frequency and duration of anode effects, amount of alumina covering over the anodes, metal tapping, anode change, etc. The temperature of the cells was measured manually by an immersion type metal clad thermocouple and corrective measures were taken after analyzing different parameters. The bath and metal pad levels were measured by specific measuring rods. The levels were maintained to predetermined values. The bath samples were taken out for monitoring the ratio of sodium fluoride to aluminum fluoride, and the alumina concentration. The successive alkaline $(\mathrm{KOH})$ and acidic $(\mathrm{HCl})$ titrimetric method $2 \mathrm{~d}$ was used for determination of the bath ratio and the LECO technique $^{9}$ for determination of alumina contents. A series of experiments was performed to determine the minimum bath ratio for $3 \%$ alumina concentration and also to study the alumina solubility.

Total cell voltage is comprised of three different contributions, which are: the decomposition voltage for the overall reaction (influenced by cell temperature and alumina concentration), excess voltage due to polarization of the electrodes (depends on operating conditions), and the ohmic voltage drop (due to the resistance of various sections of the cell). Nine different types of voltage loss measurements were made to ensure proper contacts, and to find out the distribution of the cell voltage (Table 1). The voltage measurements included clamp/anode-rod drop, anode-rod/stud drop, stud/anode-block drop, anode-block drop (from upper surface of the anode to a point in the anode block located $5 \mathrm{~cm}$ above the bath level), total anode drop (from anode bus bar to the point in the anode block located $5 \mathrm{~cm}$ above the bath level), cathode drop (from Al-metal pad to collector bar), collector bar connection loss, external losses (strap to bar 
connections + strap to bus bar welding joints + riser- aluminum to aluminum-connections + riser flexibles to anode bus bar welding joints) and total cathode drop (from Almetal pad up to the next anode bus bar).

Table 1. Voltage $(-\mathrm{mV})$ distribution observed in the Hall-Herault cells.

\begin{tabular}{lr} 
Reversible cell potential & 1,225 \\
Overvoltages $($ anode $=510$, cathode $=80)$ & 590 \\
$i R$ drop in electrodes $($ anode $=420$, cathode $=680)$ & 1,100 \\
$i R$ drop in electrolyte & 1,535 \\
Total cell voltage $(-\mathrm{mV})$ & 4,450 \\
\hline
\end{tabular}

\section{Results and Discussion}

\section{Energy consumption}

The voltage drops observed in the cell are demonstrated in Table 1 and the energy consumption was found to be $14.0 \mathrm{k} \mathrm{W} \mathrm{h} \mathrm{kg}^{-1} \mathrm{Al}$. If the energy required to maintain the cell at $960^{\circ} \mathrm{C}$ is taken into account, the energy efficiency of the process was only $33 \%$. The $i R$ drops in the cell are large, which may be ascribed to the low conductivity of carbon, a large interelectrode gap, gas bubbles on the anode, and undissolved alumina. The former three are mainly related to the consumable anode. Some work has been carried out in China 10 to decrease the anodic overvoltage by doping the anode with a lithium salt.

The current efficiency of the plant under our observation reached $95 \%$. Impurities, which show variable oxidation states such as $\mathrm{P}$ and $\mathrm{V}$, are particularly bad as they can be reduced at the cathode and then reoxidized at the anode, consuming current without producing any metal. Our plant faced such problem, decreasing CE from $95 \%$ to $94 \%$, when the pots were fed with alumina from an altered refinery process.

\section{Current efficiency}

The amount of aluminum predicted by Faraday's law is never obtained. It is reported that the best-equipped smelters have hit a ceiling of $95-96 \%$ current efficiency 11 . The principal loss mechanism involves reactions (2) through (5) along with the participation of impurities in the oxidation reduction reactions 6 . The four major factors which can affect these reactions, and hence the current efficiency, should be bath temperature, bath composition, cathode current density and the stability of the aluminum-bath interface.

Bath chemistry and bath temperature set the driving force at the aluminum-bath interface to transport dissolved metal into the bath where it is reoxidized. A stable aluminum-bath interface also reduces electrical shorting. An unstable metal pad results from the motor action produced by horizontal currents in the aluminum interacting with the vertical magnetic field of the cell2c. Horizontal currents are caused primarily by undissolved alumina sludge formed under the aluminum and to a degree by poor anode current balance. The sludge forms in the bath-filled capillary between the aluminum and the carbon bottom of the cell. When the bottom is wetted by aluminum, there is no capillary and hence no place for sludge to form and destabilize the cell. There have been reports that $\mathrm{TiB}_{2}$ composite coatings applied to the carbon cathode increase the cell's stability and increase current efficiency by one to four percent 12,13 . But no mechanism is presented to explain this improvement. A likely mechanism is being proposed. The $\mathrm{TiB}_{2}$ composite coating improved the wetting characteristic of the carbon cathode resulting in an aluminum-wetted surface, which in turn improved the stability and current efficiency of the cell.

An improved cell design for stable molten aluminum surface is being proposed here (Figure 2). In place of a plane carbon cathode there should be a raised area of aluminum-wetted material under each anode. The top of the raised area should have the same shape and size as the bottom of the anode on it. Molten aluminum deposited onto the raised surface will drain down the sides of the wetted block into channels leading to an aluminum

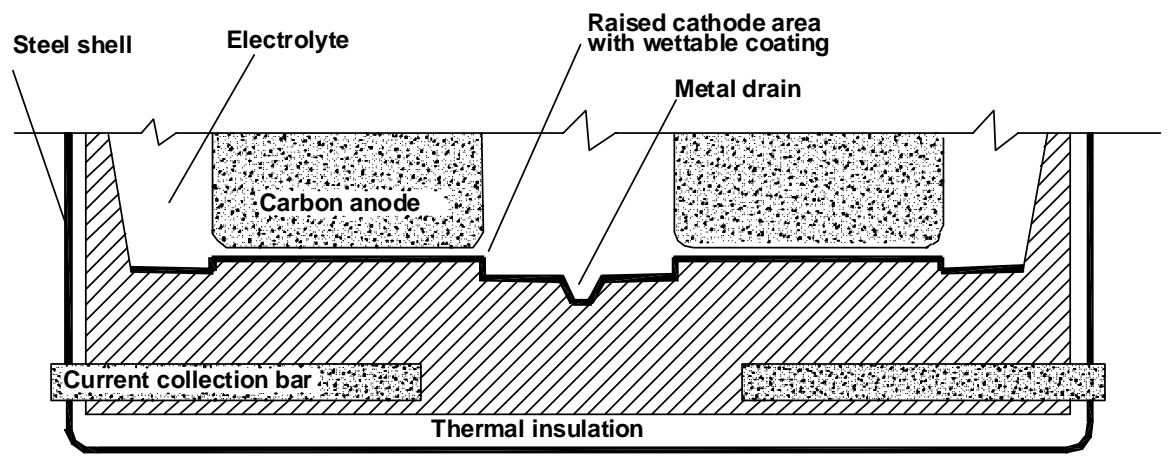

Figure 2. Schematic view of the conceptual cathode design. 
collection area. The thin film of aluminum on the raised surfaces will not be affected by electromagnetic forces. There will be no waves, swirls and electrical shorting. Anode and cathode current densities will be essentially the same. A maximum cathode boundary layer will form producing the maximum current efficiency consistent with the bath composition, temperature and current density. Besides this, the stable aluminum interface will allow a reduction of the cathode-to-anode distance producing a lower cell voltage. This combined with the higher current efficiency will improve the power efficiency. The improvement can be optimized further by simulation of current distribution and can be estimated quantitatively only by performing experiments on the modified cell as the process includes many highly coupled phenomena. The results of such study would be published only after the conclusion of the next stage of the project.

\section{Bath composition}

Molten cryolite, having a high solubility for alumina, is the major component of the bath. The most common additives are $\mathrm{AlF}_{3}$ and $\mathrm{CaF}_{2}$, which serve to reduce the liquidus temperature. Haupin ${ }^{14}$ has excellently reviewed the effect of additives on the properties of baths. The objectives in changing the bath composition are to lower the temperature, raise the current efficiency, lower the voltage, maintain operating stability and decreasing emissions while maintaining proper ledge and not generating sludge under the metal pad. Even a slight change in bath composition may upset the proper functioning of the cell. A series of experiments was performed to determine the minimum possible bath ratio for $3 \%$ alumina concentration. It was found that a bath ratio $\left(\mathrm{Wt} \%\right.$ ratio $\left.\mathrm{NaF} / \mathrm{AlF}_{3}\right)$ lower than 1.11 was detrimental to operational stability, probably due to a decrease in solubility of alumina resulting in the formation of insoluble agglomerates. Cells exploiting high $\mathrm{AlF}_{3}$ baths require maintaining an almost constant bath composition 15 . They require a careful feeding of alumina controlled by computer systems using sophisticated software, such as the Track System 16 and other modifications, which are under test in Alumar. Alumina concentration is usually kept in the range of 2-5\%. Lower concentrations have risk of anode effect while higher concentrations have risk of sludge formation. Production results have revealed that operating with low bath ratios contribute to high current efficiency. Control of granular distribution of the feed alumina is also very important. As for example, feeding $90 \%$ fraction of +325 mesh alumina in place of $82 \%$ decreased the frequency of anode effects in our test cells.

It has become widely appreciated in recent years with the more open market in alumina supplies that the physical nature of alumina used in aluminum reduction plants can greatly influence the operation of the cells $17-19$. The author has recently started a research work at Alumar to study the impact of the physical nature and mode of feeding of alumina on the functioning of the cell. Preliminary results have shown that the dissolution of alumina is a two step process: a part of the batch becomes dispersed and dissolves rapidly (within one minute) while the rest forms aggregates that dissolve at a significantly slower rate. The portion that dissolves rapidly increases with decreasing alumina batch size, increasing convection in the bath and turbulence on the bath surface.

\section{The cathode lining}

Both the cryolite-alumina melt and liquid aluminum are extremely corrosive materials and very few materials can withstand their corrosive action at $1000{ }^{\circ} \mathrm{C}$. Carbons, graphite and refractory borides (particularly $\mathrm{TiB}_{2}$ ) are the only electronic conductor materials that are satisfactory. Preformed blocks of semi-graphitized carbon are generally used for the lining. Carefully selected quality materials are essential for long life of the pots. In the plant under our

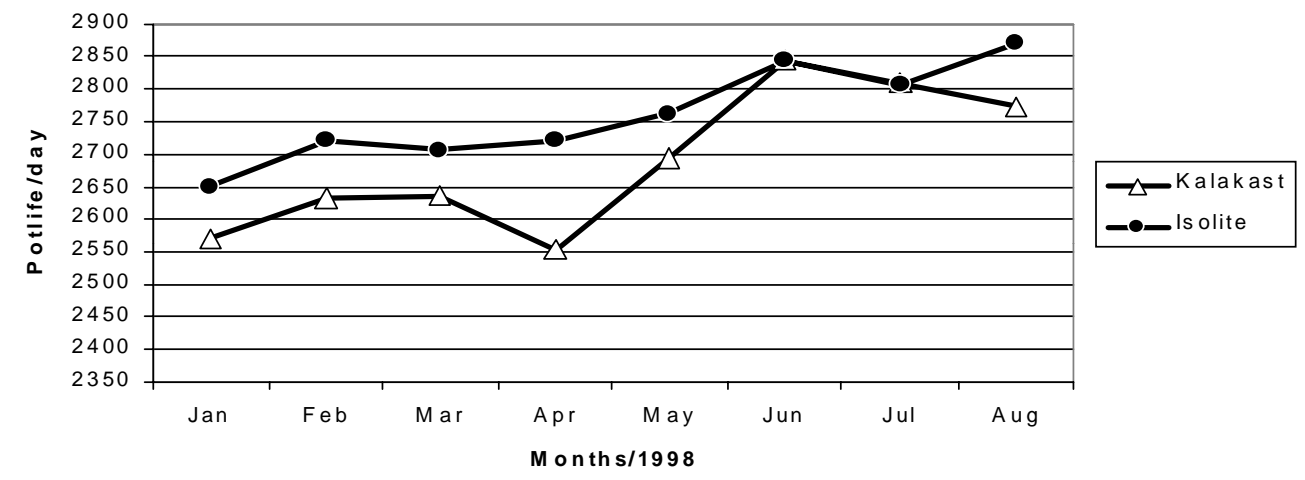

Figure 3. Effect of the substitution of Kalakast by Isolite Concrete in potlining. 
observation it was found that substitution of Kalakast by Isolite Concrete increased the average pot life (Figure 3). Normally the electrical resistance of the cathode increases with time and the lining is rebuilt after 1200 to 3000 days' operation. One of the main causes suggested for the cathode failure is the penetration of sodium metal in the lining with the formation of $\mathrm{C}_{60} \mathrm{Na}$ and $\mathrm{C}_{68} \mathrm{Na}$ intercalation compounds ${ }^{20}$ between the graphite layer, causing swelling and disruption ${ }^{21}$. The $\mathrm{TiB}_{2}$ composite cathode coating proposed in the previous paragraph may result in improved cathode life, as it has been reported 22 to be sodium resistant and aluminum wettable.

\section{The anode}

The consumable carbon anode currently used has several disadvantages. It has an overvoltage of about $0.5 \mathrm{~V}$ and is an important source of impurities. The uneven consumption of the electrode creates disturbance in interpolar distance. A major part of aluminum reduction cost (about 20\%) is contributed by carbon anodes $2 \mathrm{~b}$. These problems have stimulated extensive investigations. Several formulations of aggregate coke, binder pitch and the paste material for anodes has been reported 10 . The optimization of space utilization in the pot by changing the dimensions of the anodes and their relative position may have a significant improvement in economics of the smelter. In our observation plant each cell had two rows of 12 each of prebaked carbon anodes as shown in Figure 4. On analyzing the number of burnoffs during a period of six months it was noted that the anodes located on down-stream and on the pot-ends had more burnoff in comparison to the up-stream ones (Figure 5). Raising the level of these anodes by $4 \mathrm{~cm}$ resulted in decreasing the number of burnoffs. The down-stream curve (Figure 5) demonstrates that the anodes located on the ends (1, 12 and to a lesser extent 2,11$)$ and in the central part $(6$ and to a lesser extent 5,7 ) of the cell were more exposed to

(a)

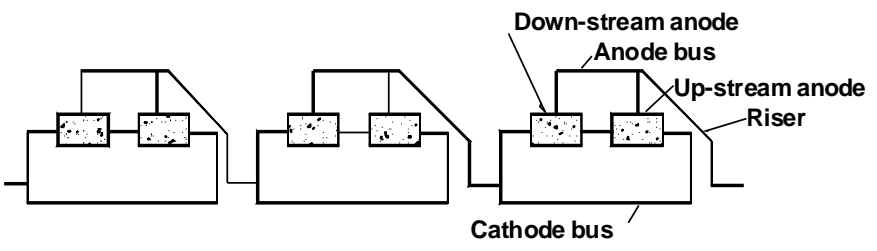

Up-stream anodes

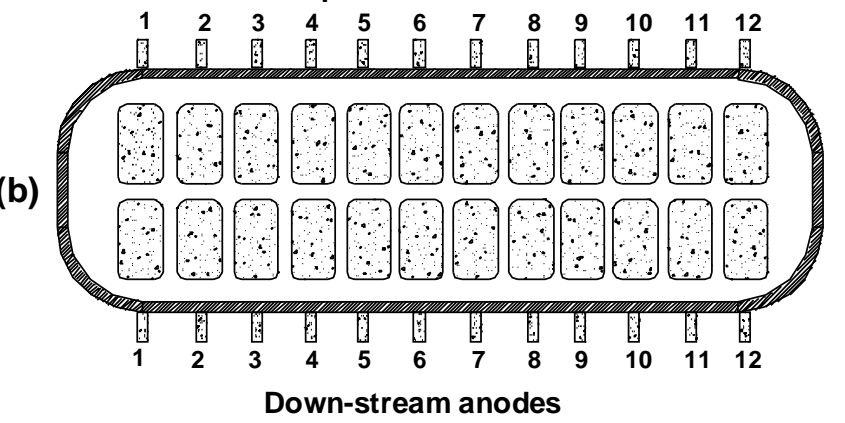

Figure 4. (a) Schematic of cathode bus, anode bus, risers, up-stream anode and down-stream anode. (b) Plan view of two rows of 12 each of prebaked carbon anodes placed in a cell (Relative position of up-stream and down-stream anodes).

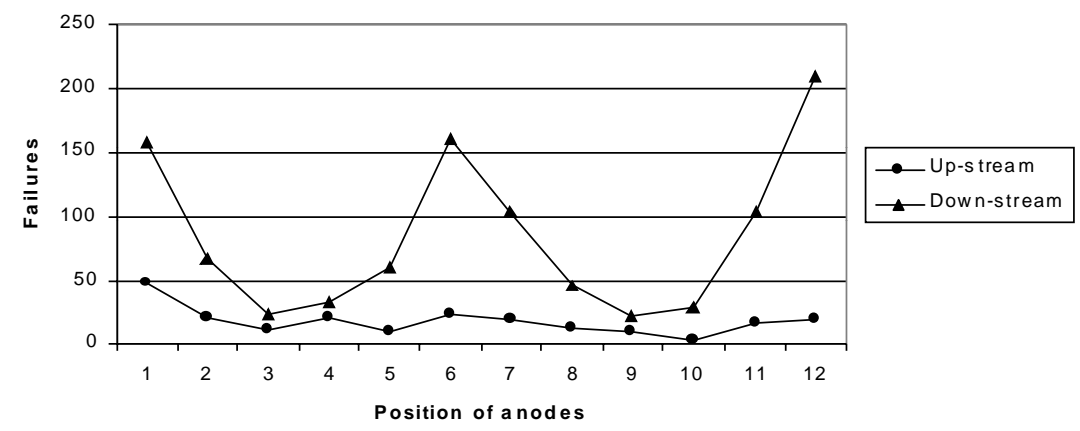

Figure 5. Distribution of anode failures according to their relative position on up-stream and down-stream during the 1 st semester of 1998 . 
the burnoff condition. This may be attributed to the strong magnetohydrodynamic phenomenon in cells functioning at a very high amperage and with such bus bar design and anode riser configuration 23 . The complex metal circulation pattern and a combination of a swirling and gyratory motion superimposed by metal pad surface waves may lead to short-circuiting and burnoffs. The proposed metal drained cells will be free from such problem.

\section{Conclusion}

The results of the study show that the energy consumption of the electrolyser is very high. Development of an inert anode and a stable cathode lining and control of the metal pad turbulence are vital for the cost reduction of the aluminum process. Horizontal currents interacting with the vertical component of the magnetic field are a significant cause of metal pad turbulence. Aluminum-wetted cathode blocks have no place for sludge to form under the metal pad and thereby cause horizontal electric current flow in the metal pad. By eliminating this source of instability, current efficiency should be improved.

If the cathode is redesigned to be an aluminum-wetted and drained cathode, as described earlier, the ultimate aluminum-bath interface stability will result. There will be no aluminum-to-anode shorting. This should provide the maximum current efficiency for a given bath composition, current density and temperature. The stable aluminum interface should also allow a reduction of the anode-to-cathode distance producing a lower cell voltage. The higher current efficiency and lower cell voltage will improve the power efficiency.

\section{Acknowledgements}

The author is indebted to UFPB-CCT-PRODENGE and ALUMAR for providing facilities for this work and to the operation engineers for useful discussions.

\section{References}

1. Grjotheim, K.; Krohn, C.; Malinovsky, M.; Matia-sovsky, K.; Thonstad, J. Aluminium Electrolysis - Fundamentals of Hall-Heroult Process; Alumi-nium-Verlag, Dusseldorf, 2nd Edition, 1982, p. (a) 6, (b) 394.

2. Grjotheim, K.; Welch, B.J. Aluminium Smelter Technology; Aluminium-Verlag, Dusseldorf, 2nd Edition, 1988, p. (a) 5, (b) 158, (c) 161, (d) 254.

3. (a) Prasad, S. Trat. Superficie 1998, 87, 32; (b) Prasad, S. 1996, 76, 18; (c) Prasad, S. 1993, 58, 23.

4. Prasad, S. Braz. J. Chem. Eng. 2000 (in press).

5. Prasad, S.; Oliveira, L.G. J. Indian Chem. Soc. 1997, $71,556$.

6. Solli, P.A.; Haarberg, T.; Eggen, T.; Skybakmoen, E.; Sterten, A. Light Metals; Warrendale, PA, 1994, 195.

7. Thonstad, J.; Rolseth, S. Electrochim. Acta 1976, 23, 223.

8. Sterten, A. Light Metals 1991, 445.

9. Tarcy, G. P.; Rolseth, S.; Thonstad, J. Light Metals 1993, 227.

10. (a) Liu, Y.; Xiao, H. Proc. Intl. Symp. Molten Salts, Honolulu, 1987,744 ;(b) Liu, Y.; Xiao, H., Chen. Z. Light Metals 1989, 275; (c) Liu, Y.; Xiao, H/; Chen, Z. Light Metals 1993, 599; 1995, 247.

11. Forberg, H.O. Light Metals 1996, 313.

12. Sekhar, J.A.; Nora, V.; Liu, J. Met. Trans. B, 1998, 29B, 59.

13. Zhang, H.; Nora, V.; Sekhar, J.A. Materials Used in the Hall Heroult Cell for Aluminum Production; TMS; Warrendale, PA, 1994.

14. Haupin, W.E. J. Metals 1994, 28.

16. Silva, A.F. An. V Simp. Tec. Ind. Alumínio, São Paulo, 1995, 265.

17. Haverkamp, R.G.; Welch, B.J.; Metson, J.B. Light Metals 1994, 365.

18. Kvande, H.; Moxnes, B.P.; Skaar, J.; Solli, P.A. Light Metals 1997, 403.

19. Issaeva, L.A.; Poliakov, P.V.; Blinov, V.A.; Mikhalev, I.G.; Buzunov, V.I. Light Metals 1998, 507.

20. Asher, R.C. J. Nucl. Inorg. Chem. 1959, 10, 238.

21. Brilliot, P.; Lossius, L. P.; Oye, H.A. Aluminium 1981, $5,1746$.

22. Sekhar, J.A.; Bello, V.N.; Liu, J.; Duruz, J.J. Light Metals 1995, 507.

23. Oye, H.A.; Welch, B.J. Journal of Metals, 1998, 18. 